\title{
A CONFIGURAÇÃO DO ESPAÇO dOS LIVROS NO INTERIOR DA SALA DE AULA'
}

THE CONFIGURATION OF THE BOOKS'

SPACE WITHIN THE CLASSROOM

\section{LA CONFIGURACIÓN DEL ESPACIO DE LIBROS}

EN EL INTERIOR DE LA CLASE

Ilsa do Carmo Vieira Goulart ${ }^{2}$

\section{RESUMO}

Este texto assume por objetivo apresentar e compreender o modo como os livros estão dispostos em diferentes espaços físicos, no interior da sala de aula, e como são percebidos pelos docentes e discentes, regulamentando ações e atuações dos sujeitos. Para tanto, realiza-se uma pesquisa de campo, a partir da coleta de diferentes imagens dos ambientes escolares em que os livros estão expostos. A análise das imagens se embasa nas concepções teóricas sobre o "espaço" de Rodríguez, articulada à ideia de cultura escolar, na percepção de Vidal e de cultura material escolar de Viñao Frago e Escolano Benito. A reflexão embasa-se, ainda, na concepção de materialidade do livro e de representação, segundo Chartier. As observações das imagens sinalizam ações de propagação de um ambiente escolar de interação com o livro, caracterizadas ora pela mobilidade do espaço físico, ora determinadas pela necessidade da visibilidade e demarcação de um espaço estável, de modo a priorizar o acesso aos livros e o acomodamento do leitor.

PALAVRAS-CHAVE: Livros. Espaço físico. Cultura material escolar.

\section{ABSTRACT}

This text assumes for present and understand how the books are arranged in different physical spaces, inside the classroom, and how are they perceived by teachers and students, by regulating actions and performances of the subjects. To this end, a field research, from the collection of different images of the school environments in which the books are exposed. The analysis of the images if the theoretical concepts behind about space to articulate the idea of Rodriguez, school culture, the perception of Vidal and school material culture of Viñao Frago and Escolano Benito. Upon reflection, in the design of materiality of the book and, according to Chartier. The observations of the images indicate actions of spreading a school environment of interaction with the book, characterized now by the mobility of physical space, now determined by the need for visibility and demarcation of a normal space, in order to prioritize access to the books and the taming of the reader.

KEYWORDS: Books. Physical space. School material culture.

\section{RESUMEN}

Este texto asume por objetivo presentar y comprender el modo de como los libros están dispuestos en diferentes espacios físicos, en el interior de la clase, y como son percibidos por los docentes y discentes, regulamentando acciones y actuaciones de los sujetos. Por lo tanto, se realiza una investigación, a partir de la colecta de diferentes imágenes de los ambientes escolares en que los libros están expuestos. El análise de las imágenes se apoia en las concepciones teóricas sobre espacio de Rodríguez, articula la ideia de cultura escolar en la percepción de Vidal y de la cultura material

\footnotetext{
${ }^{1}$ Este texto trata-se da ampliação do trabalho apresentado no IV Congresso Internacional de Literatura infantil e Juvenil, realizado pelo CELLIJ, em 2015, que contou com o apoio financeiro da Fundação de Amparo à Pesquisa de Minas Gerais - FAPEMIG.

2 Doutora em Educação, pela Faculdade de Educação da UNICAMP. Professora do Departamento de Educação da Universidade Federal de Lavras. Lavras, Minas Gerais - Brasil. http://orcid.org/0000-0002-9469-2962. Email: ilsa.vieira@uol.com.br.
}

Submetido em: 22/02/2016 - Aceito em: 25/05/2016

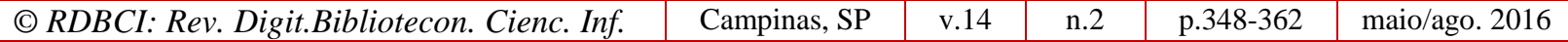


escolar de Viñao Frago y Escolano Benito. La reflexión se basea, aún, en la concepción de la materialidad del libro y de la representación, de acuerdo con Chartier. Las observaciones de las imágenes señalizan acciones de la propagación de un ambiente escolar de integración con el libro, caracterizadas ora por la mobilidad del espacio físico, ora determinadas por la necesidad de la visibilidad de un espacio estable, de tal modo a priorizar el acceso a los libros y a la comodidad del lector.

PALABRAS-CLAVES: Libros. Espacio fisicos. Cultura material escolar.

\section{INTRODUÇÃ̃o}

Pra mim, livro é vida; desde que eu era muito pequena os livros me deram casa e comida.

Foi assim: eu brincava de construtora, livro era tijolo; em pé, fazia parede, deitado, fazia degrau de escada; inclinado, encostava num outro e fazia telhado.

E quando a casinha ficava pronta eu me espremia lá dentro pra brincar de morar em livro.

De casa em casa eu fui descobrindo o mundo (de tanto olhar pras paredes). Primeiro, olhando desenhos; depois, decifrando palavras.

Fui crescendo; e derrubei telhados com a cabeça. Mas fui pegando intimidade com as palavras. E quanto mais íntimas a gente ficava, menos eu ia me lembrando de consertar o telhado ou de construir novas casas. Só por causa de uma razão: o livro agora alimentava a minha imaginação.

(BOJUNGA, 2004)

Considerando que o leitor iniciante se aproxima de um livro movido por diferentes interesses, seja de manipular, de sentir a textura de suas páginas entre os dedos, de deixar os olhos se deliciar com as imagens, realizando uma leitura minuciosa sobre cada detalhe, seja, apenas, conforme a epígrafe, para "brincar de morar em livro", o objeto-livro configura tanto um espaço provocador de ações e de relações leitoras entre o leitor e a materialidade da obra, quanto um espaço físico e substancial em que se apresentam e se articulam práticas de leitura, como apontam os estudos de Goulart (2009, 2011, 2012).

Diante disso, este trabalho parte de duas premissas: uma que considera o espaço, não limitado à demarcação de um ambiente físico, mas como algo mais abrangente: como um ato de constituição da existência humana, visto que somos um "ser espacial", segundo Muños Rodríguez (2005), o espaço integra um posicionamento do ser frente ao ambiente atribuindolhe um significado; e também, como uma una "especie de taller", segundo Escolano Benito (2000), que reflete na estrutura física os modos de conceber a organização do processo de ensino-aprendizagem, de dispor elementos e das práticas que configuram este sistema.

Outra articula-se a pensar no livro como um objeto que cria espaços de reflexão, deleite, encontros com a imaginação, ou ainda, como espaço de informação, estudo, cansaço e frustração, seja nas mais variadas possibilidades, o livro permite ao leitor um universo de interação e de produção de sentidos, também pela materialidade. 
Frente a esta concepção de que a materialidade do livro pode insinuar leituras e modos de compreensão, indicando a construção de um mundo imaginário, este trabalho articula-se na conjectura de que a disposição e ornamentação das obras num dado espaço físico podem provocar no leitor um modo distinto de aproximação ou distanciamento do ato de ler.

$\mathrm{Na}$ onda do mercado editorial de interatividade e inventividade, entre o leitor e o livro, criam-se espaços diversos para que a relação leitor-leitura aconteça. O fato do livro ser percebido como um produto altamente rentável, quesito predominante que mobiliza este ramo da economia, justifica a preocupação com a qualidade da produção da materialidade da obra, com vista na sua recepção. Tal preocupação torna-se um indício d e que a movimentação publicitária em relação à divulgação da obra, assegura certa visibilidade, exposição e apreciação do livro nas livrarias, em catálogos impressos e nas vitrines virtuais.

Ao observar que o código do consumidor no Art. 36 descreve que "a publicidade deve ser veiculada de tal forma que o consumidor, fácil e imediatamente, a identifique como tal" (BRASIL, 1990), o que remete à ideia de que identificar o produto, deva ser além de oferecer as informações básicas, também deva a permitir o acesso às informações, no caso do objetolivro, entende-se a possibilidade de manuseio, o contato físico de pegar e de folhear, compreende um modo de identificação deste produto da cultura escrita.

Por isso, a visibilidade das informações, como título e imagens, a acessibilidade à obra se mostram quesitos centrais na disposição dos objetos-livros para o leitor-consumidor. Preceitos que orientam os modos de acomodação dos livros nos espaços públicos e privados, como livrarias, bibliotecas, feiras de exposição, entre outros, num olhar meticuloso, estratégico e criterioso de posicionar o objeto-livro, com a finalidade de atrair a atenção do leitor.

Este movimento formador de comportamentos e ações em relação ao objeto-livro, instalado pela indústria cultural na sociedade contemporânea, mostra-se consonante ao processo civilizatório de Norbert Elias, apresentado nos estudos de Tozzi (2013, p.137), os objetos-livros são formadores pelo fato de trazer consigo um determinado modo de "[...] ser e estar no mundo, que apresentam às crianças uma ordem para os espaços de sua existência e expressão, que funcionam reorganizando simbolicamente os lugares ocupados por públicos que detêm sua propriedade ou apropriação conformada a certa prática”.

Os livros, segundo a autora, materializam processos de civilidade, o que repercute nas instituições educativas um desencadear de ações, atuações e comportamentos indicadores de uma remodelação sociocultural. Educam corpos e modos de agir, conformam interesses, aspirações e necessidades.

O ambiente escolar torna-se, ao mesmo tempo, revelador de diferentes culturas e constituidor, do que se pode chamar, de uma cultura escolar através das instaurações de práticas híbridas, de modo que a convivência com culturas diversas acaba por formar-se uma cultura determinante, assomando-se saberes das culturas familiares, infantis, docentes, administrativas, locais, econômicas, entre outras. 
Diante da demarcação publicitária de ordem socioeconômica, que potencializa o espaço físico como sinalizador e provocador de modos de recepção e consumo dos produtos da cultura escrita, é possível perceber esta influência na formação de uma cultura material nas instituições escolares a partir da observação de imagens do espaço físico para o objeto-livro? Qual concepção da ação leitora articula e sustenta a disposição dos materiais de leitura, especificamente aos livros, na articulação determinado lugar no interior da sala de aula?

Impulsionada por tais questões, esta pesquisa propõe-se a analisar e a compreender como se configuram o espaço físico no interior da sala de aula, em que o livro é colocado em destaque, como também, o modo como é percebido pelos docentes e discentes, a ponto de regulamentar ações e atuações pedagógicas.

Este trabalho desenvolve-se a partir de uma pesquisa de campo, realizando uma coleta de dados a partir de imagens de diferentes espaços escolares do interior de salas de aula em que o livro é exposto. Para tanto, assume-se como embasamento teórico as concepções e estudos desenvolvidos a respeito de espaço de Muños Rodríguez (2005) e Carpinteiro e Almeida (2008), articulado à ideia de cultura escolar, na perspectiva de Vidal (2001, 2009), Vidal e Faria Filho (2000, 2005) e de cultura material escolar de Viñao (1995) e Escolano Benito (2000). O estudo embasa-se na concepção de representação e de materialidade do livro, segundo Chartier (2009), entre outros autores que contribuem para a compreensão do lugar que o livro ocupa na escola.

\section{O LIVRO COMO OBJETO CONSTITUIDOR DE UMA CULTURA MATERIAL ESCOLAR}

A escola como instituição educativa constitui-se tanto de uma estrutura física, concreta e edificada, quanto de uma estrutura humana, que é formada e construída a partir de ações, de relações e de interações entre pessoas e entre a pessoa e o conhecimento. Viñao Frago (1995), ao falar sobre cultura, organização e escola, ressalta que esta última, por ser uma instituição, não está constituída por apenas uma cultura escolar, mas por culturas escolares, as quais são definidas por ele como o conjunto de aspectos institucionalizados, aspectos estes formados por vários elementos e por diferentes níveis:

\footnotetext{
"Conjunto de aspectos institucionalizados" - incluye prácticas y conductas, modos de vida, hábitos y ritos - la historia cotidiana del hacer escolar -, objetos materiales - función, uso, distribución en el espacio, materialidad física, simbología, introducción, transformación, desaparición...-, y modos de pensar, así como significados e ideias compartidas. Alguien dirá: todo. Y sí, es cierto, la cultura escolar es toda la vida escolar: hechos e ideias, mentes y cuerpos, objetos y conductas, modos de pensar, decir y hacer. (VIÑAO FRAGO, 1995, p.68)
}

A cultura escolar é composta não apenas de práticas, ações, condutas, ideias, modos de fazer e de pensar, como também de uma materialidade física de corpos e de objetos. $\mathrm{Na}$ formação de uma cultura escolar não há uma predileção ou uma hierarquia de valoração entre 
esses aspectos; todos esses elementos juntos, organizados e em interação é que a constituem e a definem.

Viñao Frago (1995, p.69) elege três dimensões ou aspectos da cultura escolar, vistos como merecedores da atenção, do aprofundamento de estudos e de análises; são eles: "[...] el espacio, el tiempo y el lenguaje o modos de comunicación". O espaço físico é compreendido como aquele local apropriado, o território disposto e habitado, considerado uma construção social, que por se constituir de relações humanas não é neutro, mas é um símbolo das condições e das relações de quem o habita. O espaço, segundo o autor, comunica, e, por isso, participa do processo de educação. Institui uma linguagem através da materialidade que se põe à leitura, a partir dos usos e das formas distintas de se ocupar e empregar tal ambiente; das relações interpessoais, ritos e representações sociais que ali são gerados ou que se estabelecem como proximidade/distância, comunicação/emudecimento, contato/conflito; das disposições dos corpos e dos objetos e da organização e hierarquização.

Outra dimensão explorada pelo autor é a do tempo escolar, que assim como o tempo, é visto como social e humano, múltiplo e plural, características as quais lhe conferem a denominação de construção social. Esta ação implícita de construir deve-se à relação de temporalidade entre o antes, o depois e o agora (presente/passado/futuro), de "[...] una determinada temporalización de la experiencia em relación com um presente también concreto". (VIÑAO FRAGO, 1995, p.72).

Para o autor, o tempo é compreendido como uma relação e não como um fluxo de horas/dias/meses, sendo definido como um ato de representação, por ser uma capacidade de síntese e de relações que, juntamente com a memória, cria e conecta o espaço de experiências e expectativas. São essas experiências que atribuem à consciência temporal um caráter plural e diverso, configurando-se por uma perspectiva social e por uma percepção individual, as quais trazem as marcas da influência da linguagem, das maneiras de medir esse tempo e de percebê-lo, como também uma memória cultural de uma determinada sociedade.

Uma pesquisa que se integra a uma proposta de estudo a respeito da cultura escolar encontrar-se-á diante de uma esfera ampla de análise, por trabalhar com imagens e representações de uma determinada realidade e tudo o que ela envolve. Assim,

[...] cuando el historiador recupera una imagen real de la tradición escolar, también busca una identificación de los lugares en que aquella se construyó. En torno a aquel acotado territorio-institución se articulan después otras dimensiones de la educación formal: los cronosistemas en que se encauzó la duración y los ritmos de la escolaridad, los roles que jugaron los actores que cohabitaron en aquel espacio, el programa y los métodos de difusión de la cultura allí impartida, el utillaje empleado en la implementación de las actividades didácticas, los rituales y las disciplinas que regularon la marcha de la clase y las reglas y modos de examen. Todo ello fue puesto en escena en un lugar determinado que sirvió de escenario a la representación, y es reconstruido en torno a las imágenes que la historia y la memoria - tiempo reconstruido, tiempo vivido y recordado- pueden recuperar de estos contenedores materiales a los que llamamos escuelas. (ESCOLANO BENITO, 2000, p.3). 
Escolano Benito (2000) concebe que a reconstrução da realidade e da imagem do espaço escolar pode ser feita através de dois registros etnográficos, que o autor denomina de "lugar o escenario" e de "representación o textualidad". O autor trabalha com a ideia de um lugar projetado para o ensino e a aprendizagem, que aparece dotado de representação e de significado; assim, o autor analisa e descreve o espaço escolar constituído de uma arquitetura e textualidade:

\begin{abstract}
La arquitectura escolar, además de diseñar espacios educativos desde presupuestos funcionales, ordenados a servir de soporte al conjunto de acciones que constituyen la mise en scène del proceso de enseñanza-aprendizaje, constituye en sí misma una escritura, esto es, un texto dotado de significaciones. En cuanto forma de escritura, la arquitectura puede ser examinada, a este respecto, como una textualidad conformada a ciertas reglas constructivas que comportan sentido en sus propias estructuras, o como un orden que transmite, a través de sus trazados y símbolos, una determinada semántica, es decir, una cultura. (ESCOLANO BENITO, 2000, p.5).
\end{abstract}

Nesta mesma perspectiva, Vidal (2009) aponta que a cultura escolar se tornou uma importante ferramenta para se compreender a relação entre a escola e a cultura, o que permite destacá-la como produtora de uma cultura específica e como um espaço de convivência de outras culturas, sejam elas: infantil, juvenil, familiar, religiosa, entre outras. Perscrutar a cultura escolar visa uma aproximação das relações interpessoais ali construídas; são estudos que, através da “[...] percepção de tensões e conflitos no ambiente escolar e nas formas como a escola exterioriza na sociedade vêm matizando a visão homogeneizadora da instituição escolar como produção social”. (VIDAL, 2009, p.26).

A partir dessa argumentação, a autora aponta, de acordo com sua percepção, três questões das investigações acadêmicas sobre o trabalho do professor no interior da sala de aula: uma que reflete sobre a conservação e a inovação na educação; outra que trata sobre a atenção à cultura material como elemento constitutivo das práticas escolares e, por fim, outra que descreve a respeito da valorização dos sujeitos como agentes sociais.

Em relação à conservação e à inovação de práticas na educação, utilizando imagens do interior da sala de aula, Vidal $(2001,2009)$ e Vidal e Faria Filho $(2000,2005)$ destacam várias mudanças na estrutura física, material e comportamental, considerando necessário reconhecer a força de elementos estruturantes da escola na sua formação e consolidação como instituição social, bem como as alterações que foram inseridas no cotidiano escolar, seja por determinação das políticas públicas, seja pela ação dos sujeitos escolares, alterações estas que precisam ser valorizadas.

De acordo com Vidal (2009), as práticas escolares são consideradas como práticas híbridas, como ações decorrentes da mestiçagem de diferentes culturas, que são "constituídas como meio dos circuitos culturais e como forma de afirmação de suas identidades sociais". Compreender as práticas culturais como hibridação possibilita destacar a produtividade e o caráter inovador das misturas interculturais, que surgem, de acordo com a autora, da criatividade individual e coletiva de reconversão do patrimônio cultural. 
O ambiente escolar torna-se, ao mesmo tempo, revelador de diferentes culturas e constituidor de uma cultura escolar através das instaurações de práticas híbridas; da convivência com culturas diversas acaba por formar-se uma cultura determinante, assomando-se saberes das culturas familiares, infantis, docentes, administrativas, locais, etc.

A cultura material escolar, segundo a autora, abrange todos os materiais e produtos do escrever, os quais ocupam uma posição expressiva no conjunto das práticas escolares e administrativas da escola e "[...] tomados em sua materialidade, os objetos da escrita permitem não apenas a percepção dos conteúdos ensinados, mas o entendimento do conjunto de afazeres ativados no interior da escola". (VIDAL, 2009, p.31).

Partindo desta perspectiva de que os objetos da escrita trazem em sua materialidade um uso próprio que se efetua a partir deles, a pesquisa procurará olhar para os espaços dos objetos de leitura, na configuração de uma cultura material escolar.

Levando em consideração o que Chartier (2009) salienta ser importante para se identificar a maneira como os discursos sobre tais práticas se constroem em cada momento histórico, seja

[...] nas e pelas obras, ou ao menos algumas delas que se apoderam dos objetos e das práticas da cultura escrita de seu tempo para transformá-las em recursos estéticos movidos por fins poéticos, dramáticos ou narrativos. Os processos que se conferem existência ao escrito em suas diversas formas, públicas ou privadas, efêmeras ou duradouras, também se convertem no próprio material da invenção literária.

Produzidas em uma ordem específica, as obras fogem delas e adquirem existência ao receber as significações que seus diferentes públicos lhes atribuem, às vezes em muito longa duração. (CHARTIER 2009, p.42)

A obra ganha sua materialidade a partir do objeto-livro e das práticas culturais da escrita, o que lhe confere um modo específico de uso e significação. O lugar físico em que este objeto-livro é disposto, especificamente o espaço escolar, pode representar as significações que este público lhe confere.

Para Muños Rodriguéz (2005) se o espaço onde acontece a produção das ações, o planejamento da ação e sua efetuação, dimensionam e explicam a interdependência entre o sujeito e os espaços, de modo que "[...] su conocimiento y manipulación podría proporcionarnos una optimización de los procesos que ahí se desarrollan. El espacio, desde esta perspectiva, no es sólo un determinado médio físico, un escenario para nuestros comportamientos, sino también um agente activo en el proceso educativo" (MUÑNS RODRIGUÉZ, 2005, p.215).

Se conforme Muños Rodriguéz (2005, p.2015) objeto-livro se mostra um agente ativo no processo educativo, pensar na articulação do espaço em que este artefato é alocado, agrega um sentido, o modo como foi planejado, organizado, reflete um significado, simbólico e 
afetivo, "[...] pues despliegan una serie de comportamientos comunicacionales, sociales y culturales, en base a la interdependencia que mantienen con los sujetos".

\section{O LIVRO NA SALA DE AULA: ENTRE A MOBILIDADE E A DEMARCAÇÃo DA ACESSIBILIDADE}

Esta pesquisa de campo foi realizada a partir da coleta de imagens de diferentes salas de aula, localizadas na região do Sul de Minas Gerais, cedidas por professores, discentes do curso de Especialização Latu Senso em Alfabetização e Letramento, realizado pelo Instituto Federal de Educação, Ciência e Tecnologia do Sul de Minas Gerais, durante os anos de 2013 e 2014, como atividade da disciplina Literatura Infantil e Alfabetização e Letramento, ministrada pela própria autora.

O levantamento de imagens do lugar em que o livro ocupava ou do modo como se configurava sua exposição no interior das salas de aula, gerou a necessidade de observar se as imagens deste espaço dos livros estariam veiculadas ou propagadas em outros espaços, como por exemplo, no ambiente virtual. Desta forma, a pesquisa apresenta, também, a veiculação de uma publicidade de imagens dos espaços físicos, direcionada ao modo de exibição e uso do livro, em ambientes virtuais, coletadas em diferentes blogs.

As observações das imagens permitiram elencar dois modos em que os livros aparecem organizados no interior das salas de aula: um caracterizado pela "mobilidade" do espaço físico, outro pela necessidade da "visibilidade" e "demarcação" do local de realização da leitura.

\subsection{Mobilidade do espaço físico}

A observação das imagens indica, a princípio, uma configuração do lugar despreocupada com uma delimitação física, ou seja, apresenta-se mais flexível, disponibilizando certa "mobilidade do espaço físico" em que os livros estão expostos. A configuração deste ambiente aparece articulada a uma ideia de movimento do espaço e do corpo leitor, modelado pela flexibilidade e praticidade, permitindo conforto e espontaneidade do posicionamento corporal.

Embora o lugar dos livros esteja restrito ao interior de uma sala de aula, o ambiente pode ser alterado, como por exemplo na figura 1, o colchonete traz a possibilidade de adulteração do espaço, por possibilitar a versatilidade, a alternância e a locomoção, o que não impediria que este espaço da leitura acontecesse em diferentes locais no interior da sala de aula ou fora dela, até mesmo, da instituição escolar. Diante disso, identifica-se certa uma variação e interdependência do espaço físico do livro, podendo ocorrer em mobilidade irrestrita ao interior da sala, articulando uma interação entre o leitor e os materiais de leitura em diferentes espaços escolares e não-escolares. 


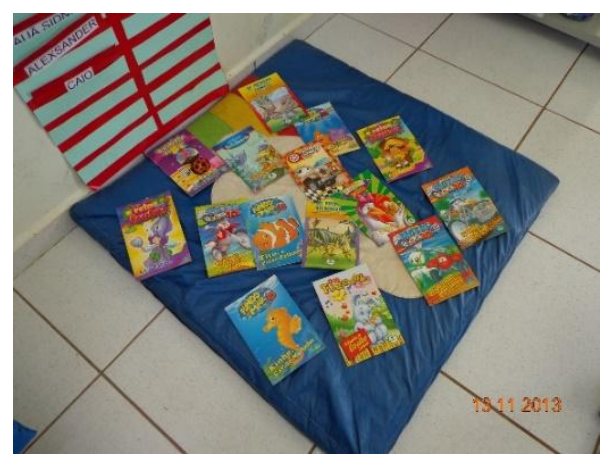

FIGURA 1 - A mobilidade dos livros no interior da sala de aula: livros em colchonetes Fonte: arquivo da autora, imagem cedida pelas alunas do curso de especialização em Alfabetização e Letramento do IF sul de Minas-Campus Muzambinho.

A organização e articulação deste espaço parece viabilizar a mobilidade dos alunos, permitir ainda um modo individualizado de leitura, em que o corpo leitor expresse suas vontades e liberdade, seja sentado ou deitado, desencadeia a espontaneidade da relação entre leitor e o objeto-livro no ato de ler. É nesse processo de interação leitor/livro, nessa relação entre um sujeito real, historicamente datado e situado, e num material concreto de leitura que se torna possível a construção de um sentido. Uma relação física que se efetua pela postura do corpo - sentado, deitado - impondo maneiras distintas de se ler, o que nos mostra Goulemot (2001).

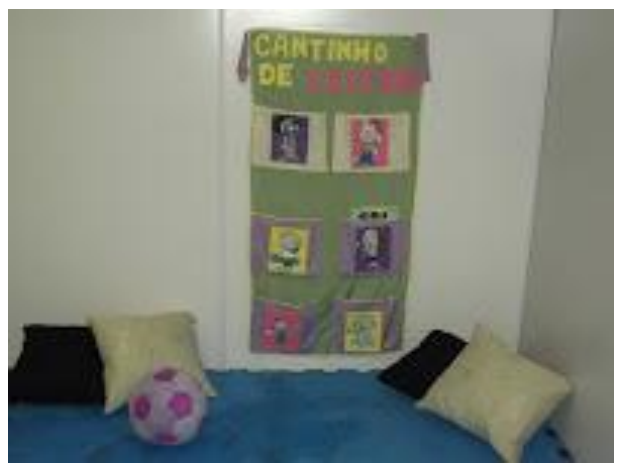

FIGURA 2 - A mobilidade dos livros no interior da sala de aula: livros em tapetes de EVA. Fonte: [http://blogdaebi.blogspot.com.br/2013/03/cantinho-da-leitura-iii.html]

A necessidade de reconhecer outros espaços em que o livro poderia estar exposto, aproxima a pesquisa do ambiente virtual. Observa-se a existência de diversos blogs que, em sua maioria, são criados por professores, com a finalidade de divulgação, de compartilhar atividades e modos de confecção e organização do espaço físico do livro. Esta exposição do livro no ciberespaço, parece também articulada pela ideia de mobilidade, de acolhimento, de expressividade, de interação, não apenas com a materialidade do objeto-livro e o leitor, mas mediada pelo espaço físico em que estes artefatos ficarão armazenados.

Em diferentes formatos, cores e tamanhos, a preferência pelas caixas se mostra vinculada a ideia de um espaço físico de armazenamento que oferece organização e mobilidade aos livros, viabilizando a circulação dos livros no interior da sala de aula. 


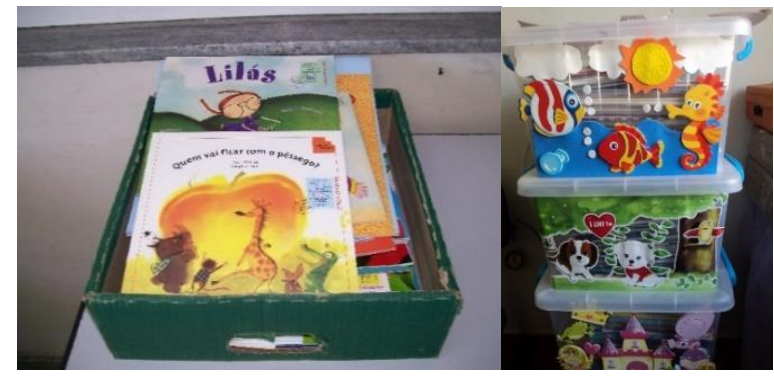

FIGURA 3 - Livros em caixas.

Fonte: arquivo da autora, imagem cedida pelas alunas do curso de especialização em Alfabetização e letramento do IF sul de Minas-Campus Muzambinho.

Os livros nas caixas propiciam uma atividade de leitura, balizada não tanto pela visibilidade, mas pela ação de seletividade da obra, gerando a necessidade de um suporte para a exposição das obras. Assim, a leitura pode acontecer em diferentes lugares, com ações que demandam um processo mais delongado do leitor ao fazer sua triagem do livro. No ato de manusear promove-se um percurso do leitor tanto entre diferentes obras, permitindo uma interação com a materialidade do objeto-livro, até a escolha permeada pela preferência, interesses e gosto do leitor, quanto uma circulação pelo lugar em que as caixas estarão expostas, entre o ir e vir de sua carteira, ou a mesa em que os livros são expostos, o leitor observa o que e de que modo os outros leitores estão realizando a leitura.

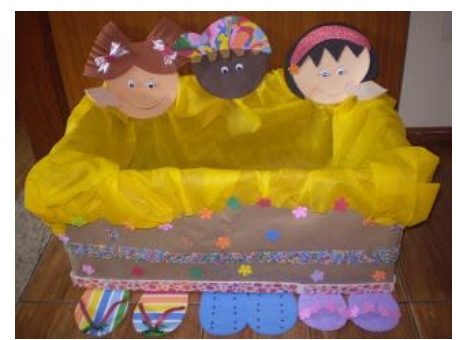

FIGURA 4 - Caixa decorada para livros

Fonte: http://decorarteatelie.blogspot.com.br/2013/05/caixas-decoradas.html

O ambiente virtual também exibe uma variedade de modelos de caixas como suportes aos livros de leitura em sala de aula, com a finalidade de divulgação de modos de armazenamento de livros. As caixas decorativas se mostram em um cenário de refinamento de cores, formas de um trabalho puramente artesanal.

Outra característica da mobilidade não foi percebida apenas na determinação de um espaço de fixação e armazenamento do objeto-livro, limitas à margem interior da sala de aula, mas também um investimento na articulação de práticas de leitura que ultrapassem a fronteira escolar.

A configuração do lugar atribuído ao livro na sala de aula, parece expandir-se na criação de um espaço de transitoriedade do objeto-livro. Desfigura-se de seu caráter estável, ao obter a possibilidade de mover-se em espaços não escolares, impulsionado pela ideia de prática de leitura deleite e compartilhada, que permite à criança levá-lo para casa e realizar a 
ação leitora em um ambiente de familiaridade, juntamente com pessoas de seu convívio, criando aproximações entre ações leitoras e relações humanas. São todas estas diversas relações entre um leitor e seu objeto-livro que possibilitam a construção de um sentido e isto só é possível por meio das atitudes do leitor (GOULEMOT, 2001).
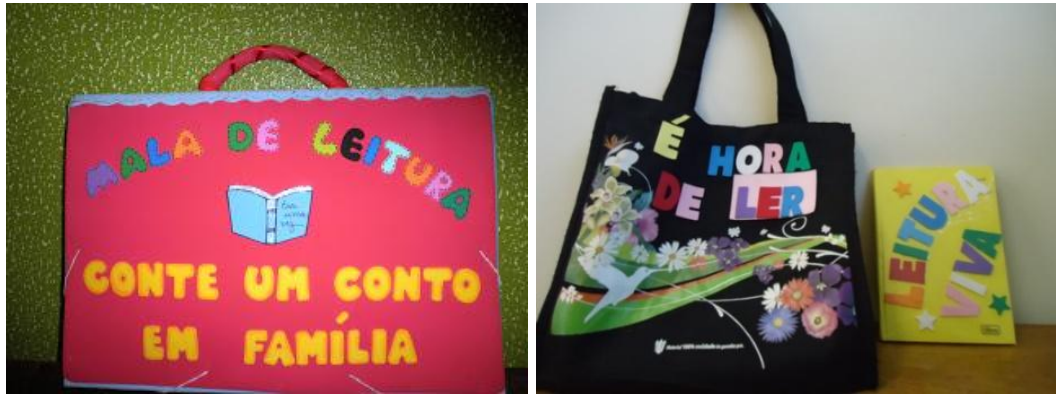

FIGURA 5 - Mala e Sacola de livros

Fonte: http://alfabetizacaocefaproponteselacerda.blogspot.com.br/2013/01/blog-post_13.html

Da mesma forma, o espaço virtual em diferentes blogs articula-se com a finalidade dar mobilidade ao livro, a partir da apresentação de modelos variados para a confecção de suportes, como pastas, sacolas, malas, entre outros, acompanhados de um refinamento artesanal para comportar tal produto cultural.

\subsection{Visibilidade e demarcação do espaço físico}

A categoria da visibilidade e demarcação do espaço físico caracteriza-se por oferecer uma determinada forma de organização do espaço estável, de modo a delineá-lo, nomeá-lo e determiná-lo, garantindo ao leitor sua identificação e possibilidade da realização da leitura num espaço único e delimitado.

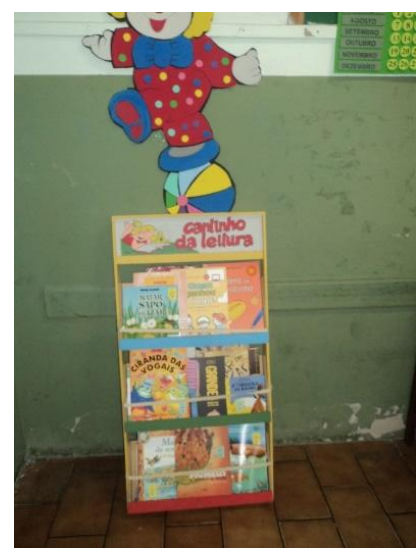

FIGURA 6 - Exposição de livros em suportes de madeira.

Fonte: arquivo da autora, imagem cedida pelas alunas do curso de especialização em Alfabetização e letramento do IF sul de Minas-Campus Muzambinho.

Dentre a estrutura física da sala de aula reserva-se um espaço nomeado de "Cantinho da leitura". De acordo com o Caderno 1 do programa de formação de professores, Pacto

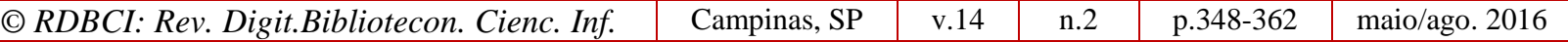


Nacional pela Alfabetização na Idade Certa (PNAIC, 2013), foram distribuídos, em 2010, 249 títulos destinados à Educação Infantil, anos iniciais do Ensino Fundamental e Educação de Jovens e Adultos. Os professores alfabetizadores vinculados ao programa de formação, receberam a coletânea de obras que contemplaram temáticas, gêneros e extensões variados, o que gerou a necessidade de se criar um espaço físico determinado para a circulação e interação das crianças com as obras no interior das salas de aula.

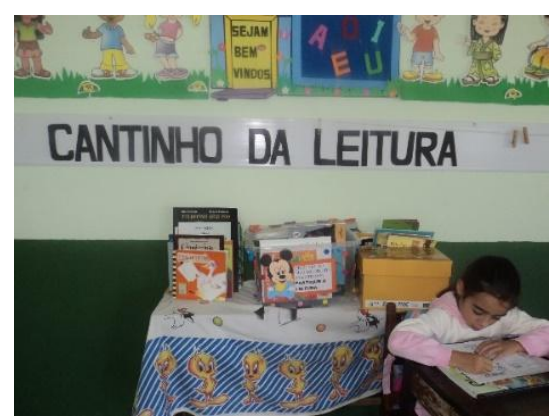

FIGURA 7 - Espaço do livro em Cantinho da leitura.

Fonte: arquivo da autora, imagem cedida pelas alunas do curso de especialização em Alfabetização e letramento do IF sul de Minas-Campus Muzambinho.
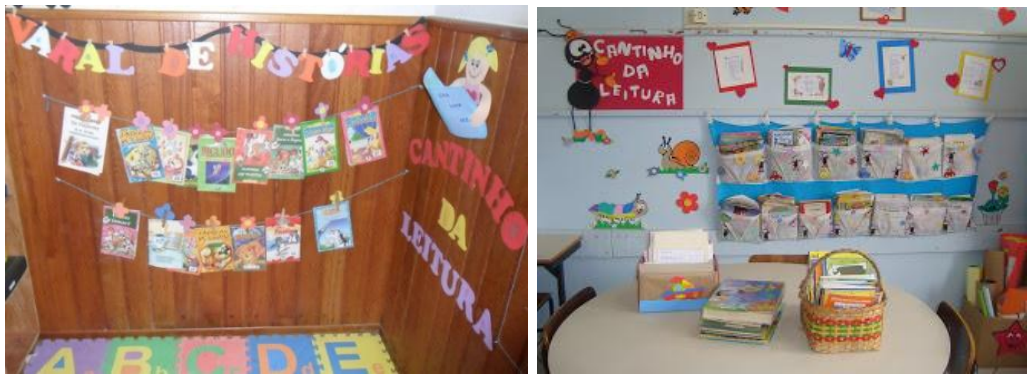

FIGURA 8 - Espaço em varal de livros

Fonte: http://eusoudonademim.blogspot.com.br/2013/03/sala-de-aula-cantinho-da-leitura.html e http://diariovirtual4ano.blogspot.com.br/2011/03/nosso-cantinho-da-leitura.html

O ambiente virtual apresenta diferentes configurações do espaço nomeado de Cantinho da leitura disponível em $\operatorname{blogs}$, que parecem disponibilizados pela finalidade de divulgação de ambientes em que o livro pode estar exposto dentro da sala de aula. Organizados em varais, envelopes confeccionados em tecidos, plásticos e EVA, ou em estantes de madeiras, observou-se uma variedade de possibilidades de confecção do espaço em que os livros são exibidos na sala de aula.

\section{CONCLUSÃO}

Esta pesquisa se propôs a apresentar e a compreender como se constituem diferentes espaços físicos no interior da sala de aula, em que os livros de literatura infantil estão dispostos, como também, o modo como são percebidos pelos docentes e discentes, a ponto de regulamentar ações e atuações pedagógicas. 
A observação de diferentes imagens em que os livros se apresentavam em exposição, gerou a curiosidade e a necessidade de buscar imagens de outros lugares de exposição dos livros, como ciberespaço, a título de comparação com a realidade analisada. O que permite à pesquisa destacar que o ambiente virtual adquiri a função de veiculação e de divulgação de espaços físicos, direcionados ao modo de organização, exposição e uso do livro, em diferentes blogs.

A análise das imagens sinaliza que o lugar que o livro de literatura ocupa nas salas de aula não se mostra neutro ou marcado pela indiferença pedagógica, mas aparece envolto de ações e atuações de práticas de leitura, preocupadas com a articulação de ambiente escolar que proporcione a interação com as obras literárias. As observações apontam um lugar ora caracterizado pela "mobilidade do espaço físico" dos livros, ora determinado pela "visibilidade e demarcação" de um espaço físico estável para a exposição dos livros de literatura infantil, ambos articulam a ação leitora e um modo de integração entre o leitor e a materialidade da obra.

Neste sentido, entende-se que o espaço do livro ultrapassa a configuração de uma estruturação física, visto que se constitui em ações e relações humanas, por isso não é neutro, mas torna-se um símbolo das condições e das inter-relações de quem o coabita. A escola se constitui de veias humanas, como afirma Fernandes (2005, p.24), “[...] não é apenas um universo de objetos. É também um mundo de pessoas e um tecido de relações interpessoais".

O que se observa no espaço criado para o livro, seja como a forma de decoração, de organização, é que a ambiência desencadeia relações interpessoais, ritos e representações de práticas de leitura que ali são geradas, que vão além do ambiente escolar. Cria-se um espaço de diálogos entre o leitor e o livro e entre leitores diversos que, conforme Viñao Frago (1995) comunica e, por isso, participa do processo educativo. Torna-se um ambiente articulador de uma relação dialógica permeada pela materialidade que se põe à leitura, a partir dos usos e dos modos distintos da realização de atividades leitoras, configurando uma dada cultura material escolar.

\section{REFERÊNCIAS}

BOJUNGA, Lygia. Livro: um encontro. 6. ed. Rio de Janeiro: Casa Lygia Bojunga, 2004.

BRASIL. Código do Consumidor. Lei no 8.078, de 11 de setembro de 1990. Disponível em: <http://www.planalto.gov.br/ccivil_03/leis/L8078.htm>. Acesso em: 22/02/2016

BRASIL. Secretaria de Educação Básica. Diretoria de Apoio à Gestão Educacional. Pacto nacional pela alfabetização na idade certa: planejamento escolar: alfabetização e ensino da língua portuguesa, ano 1, unidade 2. Brasília: MEC; SEB, 2012.

CARPINTEIRO, Antônio Carlos; ALMEIDA, Jaime Gonçalves. Teorias do espaço. Brasília: Universidade de Brasília, 2008. 
CHARTIER, Roger. (Org.) Práticas da leitura. 2. ed. São Paulo: Estação da Liberdade, 2001.

CHARTIER, Roger. A aventura do livro: do leitor ao navegador. Trad. Reginaldo de Moraes. São Paulo: UNESP, 1999.

ESCOLANO BENITO, Agostín. El espacio escolar como escenario y como representación. Revista Teias, Rio de Janeiro, v. 1, n. 2, p. 1-12, 2000.

ESCOLANO BENITO, Agostín. El livro escolar como espacio de memoria. In: OSSENBAH, G.; SOMOZA, M. (eds.) Los mauales escolares como fuente para la historia de la educación en America Latina. UNED: Madrid, 2001.

FERNANDES, Rogério. Cultura de escola: entre as coisas e as memórias. Revista ProPosições, Campinas, v. 16.n. I (46), p.19-39, jan./abr. 2005.

GOULART, Ilsa do Carmo Vieira. O livro objeto de estudo e de memória de leitura. 2009, fs. 189. Dissertação (Mestrado em Educação). Faculdade de Educação, Universidade Estadual de Campinas, Campinas, 2009.

GOULART, Ilsa do Carmo Vieira. Um livro, diferentes modos de ler. Revista Leitura: Teoria \& Prática, Campinas, v. 29, n. 56, p.27-35, 2011.

GOULART, Ilsa do Carmo Vieira. O livro que "abre caminhos": entre experiências de leitura, representações e afetividade. Revista Práticas de Linguagem, Juiz de Fora, n.3, n.1, p.1-15, jan./jun., 2012.

GOULEMOT, J. Da leitura como produção de sentidos. In: CHARTIER, R. Práticas da leitura. São Paulo: Estação da Liberdade, 2001.

MUÑOS RODRÍGUEZ, Jose Manuel. El lenguage de los espacios: interpretación em términos de educaión. Teoria y Educación, Universidad de Salamanca, vol. 17, p. 209-226, 2005 .

TOZZI, Juliana Bernardes. Educação, infância e leitura: contribuições da teoria dos processos civilizadores de Norbert Elias. Revista Pro-Posições, Campinas, v. 24, n. 2 (71), p. 127-145, maio/ago. 2013.

VIDAL, Diana Gonçalves; FARIA FILHO, Luciano Mendes. As lentes da história: estudos de história e historiografia da educação no Brasil. Campinas: autores Associados, 2005.

VIDAL, Diana Gonçalves; FARIA FILHO, Luciano Mendes. Os tempos e os espaços escolares no processo de institucionalização da escola primária no Brasil. Revista Brasileira de Educação, Rio de Janeiro, n.14, p.19-24, maio/ago. 2000.

VIDAL, Diana Gonçalves. No interior da sala de aula: ensaio sobre cultura e prática escolares. Currículo sem fronteiras, Porto Alegre, v. 9, n. 1, p. 25-41, 2009. 
VIDAL, Diana Gonçalves. O exercício disciplinado do olhar: livros, leituras e práticas de formação docente do Instituto de Educação do Distrito Federal (1932-1937). Bragança Paulista: Editora da Universidade São Francisco, 2001.

VIÑAO FRAGO, Antonio. Historia de la educación e historia cultural: posibilidades, problemas, cuestones. Revista Brasileira de Educação, Rio de Janeiro, n. 0, p. 63-82, 1995.

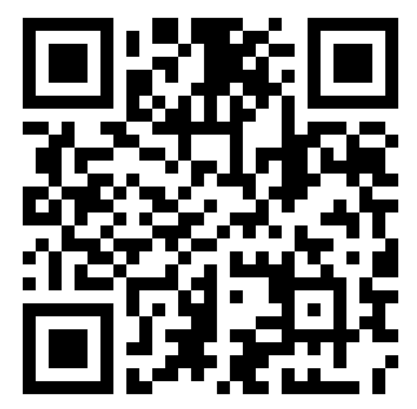

